\title{
Survey Results and an Android App to Support Open Lesson Plans in Edu-AREA
}

\author{
M. Caeiro-Rodríguez ${ }^{1}$, R. Couselo-Alonso ${ }^{1}$, L. Pereiro-Melón ${ }^{1}$, M. Rodríguez- \\ Bermúdez $^{1}$, R. Míguez-Vázquez ${ }^{1}$, M. Llamas-Nistal ${ }^{1}$, A. Blanco-Pesqueira ${ }^{2}$, A. \\ Gewerc-Barrujel $^{3}$, A. Rodríguez-Groba ${ }^{3}$, A. Alonso-Ferreiro ${ }^{3}$, F . Fraga-Varela ${ }^{3}$
}

${ }^{1}$ E.E. Telecomunicación - Universidade de Vigo (UVigo)

Campus Universitario 36312 - Vigo - Pontevedra - España

${ }^{2}$ F. Ciencias da Educación e do Deporte - Universidade de Vigo (UVigo)

Campus de Pontevedra - Pontevedra - España

${ }^{3}$ Facultade de Ciencias da Educación - U. de Santiago de Compostela (USC)

Rúa Xosé María Suárez Núñez 15782 - Santiago - A Coruña - España

manuel.caeiro@uvigo.es

\begin{abstract}
This paper introduces an open view to lesson plans focused on primary and secondary teachers. Open Lesson Plans are proposed as a special kind of Open Educational Resources. This involves the educational contents they are built on, of course. In addition, we extend the open view taking into account their development during educational use: from creation, through the observation of classroom use, to the reflections when finished. The paper introduces the results of a survey conducted among Galician teachers based on this view. It also describes functionalities available in an Android App to support this open view in the Edu-AREA platform.
\end{abstract}

Resumen. Este artículo plantea una visión abierta a las unidades didácticas dirigido al profesorado en educación primaria y secundaria. La visión abierta parte de considerar las unidades didácticas como un tipo especial de Recurso Educativo Abierto en el que es importante no sólo su composición, sino también su desarrollo y uso docente: desde su creación, pasando por su observación en el aula, hasta la reflexión una vez que se ha terminado. En el artículo se presentan resultados de una encuesta sobre este planteamiento realizada entre profesorado de Galicia. También se describen las funcionalidades disponibles en una App Android para dar soporte a través de la plataforma Edu-AREA.

\section{Introduction}

During the last years many initiatives have been carry out in order to promote OER development and adoption by teachers. The ideas of the open movement are welcomed in general. They are fully aligned to the "sharing" culture underlying new society and technological developments related to Web 2.0 (O'reilly, 2007) and UNESCO OER Declaration (2012). Nevertheless, the adoption rates and the success stories of teachers creating and adopting OERs are very low [Camilleri, 2014]. There are many reasons that explain this situation: concerns about quality, concerns about privacy, copyright and licensing issues, etc. 
Our approach to the OER world comes from trying to support and promote teaching innovation in the context of the TELGalicia research network. Particularly we are focused on primary and secondary teaching. Taking into account this goal we have been working in the development of the Edu-AREA platform [Caeiro-Rodríguez et al., 2013]: a repository/referatory of OERs. This platform offers functionalities to facilitate the operation of OERs in accordance to the 5 Rs: Retain, Reuse, Revise, Remix and Redistribute. Edu-AREA distinguishes several categories of OERs attending to their granularity: Resources (including Documents as the lowest level educational contents), Activities and Lesson Plans. From a teaching innovation point of view, teachers may not be requested to create their own educational contents, they can be available anywhere, but teachers should create their own lesson plans. More over, lesson plans need to be prepared beforehand, used and observed during the development of the educational activities, and assessed and reviewed when finished. Therefore, we developed Edu-AREA with these ideas in mind [Caeiro-Rodríguez, 2014]: to support teachers creating and sharing lesson plans during this whole process. Till this point, teachers have found the open view and the platform functionalities interesting, but as in the case of other OER initiatives, they are not doing as desired. It seems Edu-AREA doesn't provide any significant advantage or benefit. A general request from teachers was: what can this platform do to facilitate and improve my classroom activities?

Taking into account this situation we have been working in two different ways. First, we conducted a survey asking teachers about their actual management of lesson plans. We wanted to check if Edu-AREA could be useful to support their actual practices: before, during and after the real teaching. Second, we initiated the development of a solution that provides more support during their classroom activity: an Android App (available in Google Play). In this paper we show these results and reflect about the experience until this point.

The paper is organized as follows. First we introduce in next section our view about Openness of lesson plans. Next, section 3 shows the results obtained in our survey to Galician teachers. Then, we introduce the Android App to support teachers using open lesson plans in section 4 . The paper finishes with some conclusions in section 5.

\section{Openness of Lesson Plans}

Lesson plans organize what a teacher will do and say during teaching sessions. A lesson plan is a "living" entity that needs to be prepared before teaching and that can be evolved during its lifetime. The openness concept of lesson plans in Edu-AREA is not just related to the openness of the components they are made of, such as activities and educational contents, but also to the information that can be provided or generated during teaching. We consider lesson plans as "living" entities that are born, grow up, maybe reproduce and eventually die. Therefore, in Edu-AREA we attempt to capture all the relevant information about lesson plans during their whole life cycle in accordance to this open and living concept.

\subsection{Lesson Plan Components}

A lesson plan in Edu-AREA is made of by several components, see Figure 1. The left part of this figure shows a view of a lesson plan in the Edu-AREA platform. The right 


\section{CBIE-LACLO 2015}

Anais dos Workshops do IV Congresso Brasileiro de Informática na Educação (CBIE 2015)

part shows the conceptual components. Almost all components can be identified in the two parts:

- Activities. A lesson plan can include one of several activities as the different stages in which the lesson is going to be developed. For example: teacher introduction, group formation, group work, classroom debate, etc. Each one of the activities can involve some resources and also submissions, as any kind of result that learners need to provide.

- Resources. They are any kind of element that can be used during the lesson plan or activities development. Typically, educational contents such as any type of document: multimedia, image, video, slides, simulation, etc. In addition we also consider as possible resources: computer applications (e.g. a game, a wiki), electronic devices (e.g. a tablet, a gps), places to visit (e.g. a museum, a zoo), and people that can participate (e.g. a painter, a fireman).

- Technological profile and curricular profile are intended to maintain metadata related to the context in which the lesson plan is going to be developed. They are provided for classification purposes and in the future we plan to include other profiles.

- In addition, a lesson plan also involves some textual descriptions. First, a summary, involving a title, picture and a description. Second, detailed information about the goals and purpose of the lesson plan. This is shown in the central part of the web page in figure 1 . We have found many different proposals to do this in different countries, schools and teachers. Therefore we support different fields and layout arrangements for this part based on templates.
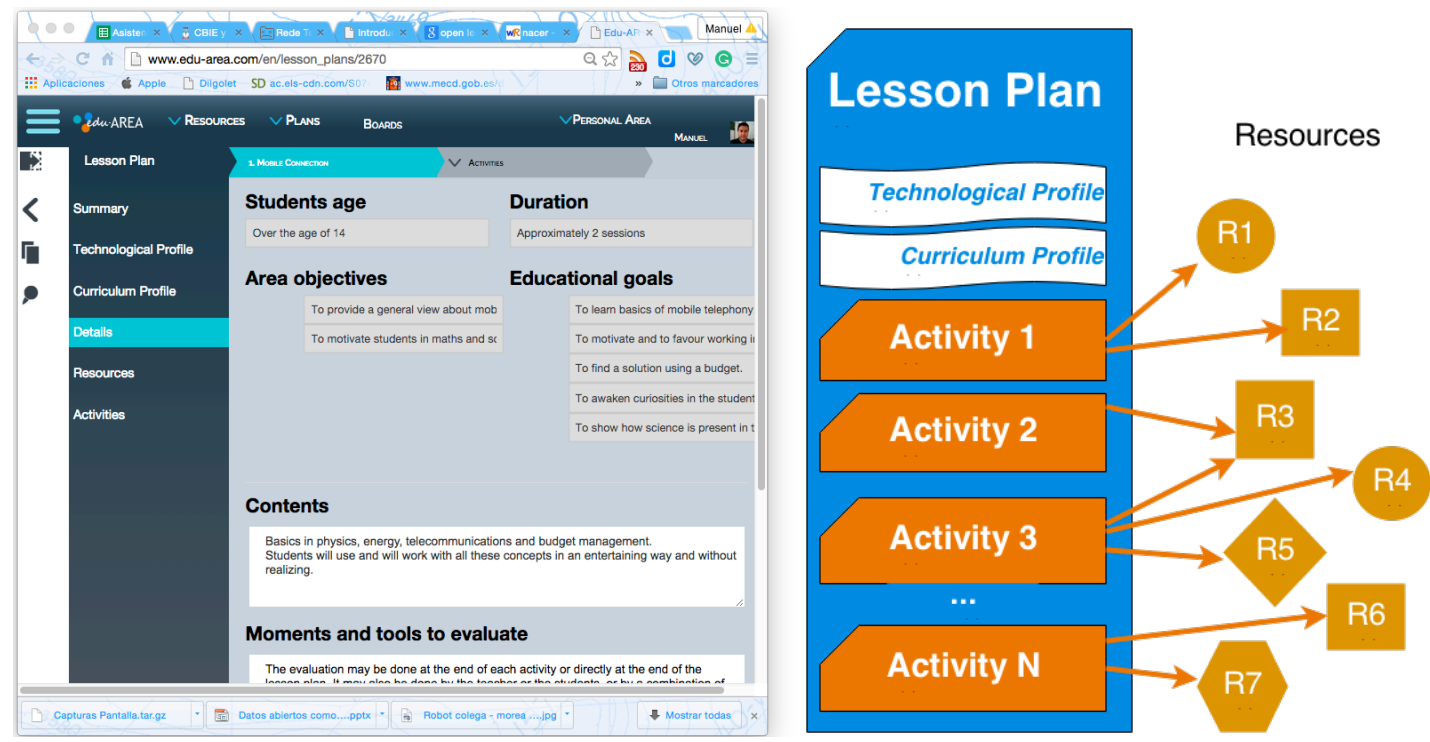

Figure 1. Lesson Plans in Edu-AREA. Left: view of a lesson plan in the platform. Right: main components of a lesson plan.

\subsection{Additional Components in Lesson Plans}

Taking into account the view of lesson plans as "living" entities we wanted to record all the information that is generated during their lifetime. This involves several information items: 
- Related to the development of the components included in previous section: where they come from? How they where evolved? etc. In Edu-AREA we record all this data, but we need to provide better interfaces to allow users to review and explore it.

- Related to the observations that can be recorded by users during its development in classroom. Edu-AREA allows teachers to capture pictures, videos, documents, code snippets, positive comments, negative comments, ideas and general comments. The registration of this information can be considered as a kind of teacher journalism.

- Related to reflections that can be provided by teachers once the educational activity is finished. These are mainly comments, ideas and reviews that can be provided by the teacher after the classroom.

In Edu-AREA teachers can link all these pieces of information to the related activities and resources.

\section{Results of a Survey to Teachers about their Management of Lesson Plans}

The survey was conducted in Galicia (Spain) from November 2014 to May 2015. We collected 387 responses from teachers in pre-university education, mainly primary and secondary education. The survey had several sections, but in this paper we focus our attention in two: how do you use and share your lesson plans, and OER knowledge.

Related to the questions about lesson plans we asked about teachers preparing lesson plans, following the lesson plan during teaching development, recording observations and reflecting when the lesson was finished. In Galicia it is mandatory for teachers to prepare lesson plans for the whole course. Therefore, we did not asked about if they prepared their lesson plans, but what was the main source for planning. More than half of the teachers answered that their plans were based on some textbook. Other answers were cooperative, collaborative, problem-based, and project based. This reflects a large use of textbooks by teachers, but also that they usually do some kind of teaching planning by themselves. Then we asked about the recording of observations during teaching: 18\% do not register anything; 69\% make annotations about the development of activities and the use of resources and 33\% also take pictures, record videos and collect documents from the classroom activities. Therefore, many teachers usually do some kind of registration and many of them use media technologies. We also asked if teachers reviewed and reflected about the experience after the classroom: $1 \%$ said never; 3\% almost never; 29\% sometimes; 50\% almost always; $17 \%$ always. Therefore, teachers usually review and reflect about their teaching experiences. These are good news. Then, we asked teachers if they published their plans, observations and reflections to be shared with others. Results are shown in Table 1. The results show that teachers mainly share with their teacher colleagues. In addition, they share much more their initial plan than their observations and reflections. In summary we interpret these results as positive, because teachers usually plan, observe and reflect. In any case, there is space for improvement.

The survey included other questions related to the knowledge about OER. First, we asked if they know what is an OER: 37\% answered "No"; $30 \%$ answered they have listen about them, but never used; $21 \%$ answered they have used OER; and 12\% answered they have produced OER. Then, we asked specific issues about OER, in order 
CBIE-LACLO 2015

Anais dos Workshops do IV Congresso Brasileiro de Informática na Educação (CBIE 2015)

to check if their understanding was good. Results are shown in table 2 and they are coherent with the answer to general question about OER.

Table 1. Teacher answers to questions about the publication of lesson plans, observations and reflections. Legend: (1) to anyone interested; (2) to other teachers in the same course; (3) others, such as parents or conferences.

\begin{tabular}{|l|l|l|l|l|}
\hline Do you publish your ... & No & Yes (1) & Yes (2) & Yes (3) \\
\hline ... lesson plan? & $23 \%$ & $29 \%$ & $47 \%$ & $1 \%$ \\
\hline ... classroom observations? & $36 \%$ & $17 \%$ & $47 \%$ & $0 \%$ \\
\hline ... after course reflections? & $57 \%$ & $8 \%$ & $31 \%$ & $4 \%$ \\
\hline
\end{tabular}

Table 2. Teacher answers to questions about OER.

\begin{tabular}{|l|l|l|l|}
\hline & Should be & Could be & Not necessary \\
\hline Are available for free? & $74 \%$ & $21 \%$ & $5 \%$ \\
\hline Can be edited or modified? & $57 \%$ & $37 \%$ & $36 \%$ \\
\hline Can be remixed with others? & $62 \%$ & $36 \%$ & $2 \%$ \\
\hline Can be re-distributed? & $65 \%$ & $32 \%$ & $3 \%$ \\
\hline Must include some license? & $44 \%$ & $35 \%$ & $21 \%$ \\
\hline Must attribute to the author? & $75 \%$ & $19 \%$ & $6 \%$ \\
\hline
\end{tabular}

\section{Edu-AREA Android App}

Edu-AREA development was initiated at the beginning of 2013. Since them we have been working in different aspects of the platform, trying to support teachers innovation in primary and secondary education. A general idea was to support teachers while planning for teaching and developing the lesson plans in their classrooms. Also reflecting about their lesson plans when they are finished and sharing with their colleagues.

Initially teachers were allowed to remix lesson plans and combine resources available in the platform. During the classroom time, teachers were allowed to review the plan and get access to the resources involved. As a second functionality we offer teachers the option to record observations and to register reflections. These functionalities were initially available just through the web.

After, we decided to develop an Android App to support a main non-functional requirement: offline functioning. Internet is a very scarce resource in many primary and secondary schools. Teachers cannot be ensured the availability of an Internet connection. In this way, Android was devised as a good solution to support teachers accessing to lesson plans and recording observations independently of Internet availability. In addition, tablets offer a confortable interface for teachers that facilitate them taking pictures and recording videos. This App is now available at Google Play for free. 
CBIE-LACLO 2015

Anais dos Workshops do IV Congresso Brasileiro de Informática na Educação (CBIE 2015)

\subsection{Access to the lesson plan components}

Figure 2 shows a screenshot of a lesson plan in the Android App of Edu-AREA. This lesson plan involves actually five presentations of several experts as in a conference. Each presentation is included as a different activity, showing a picture, title and brief description. Clicking in a certain activity the user get access to detailed information about it, including resources, more detailed descriptions, etc.

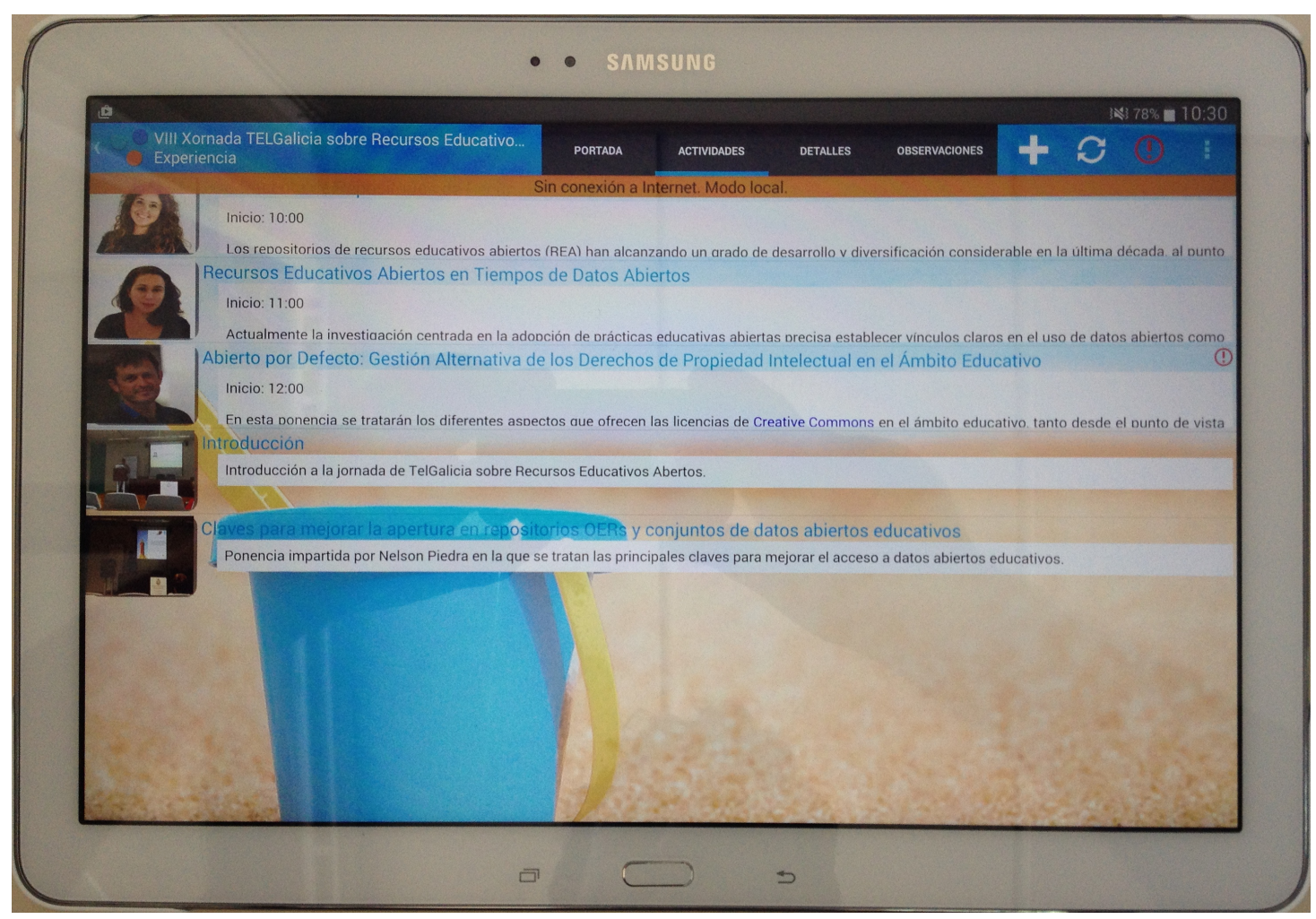

Figure 2. Edu-AREA App screen capture showing the activities of a lesson plan

\subsection{Teacher journalism}

The Android App is a perfect tool to support teacher journalism. Directly in the lesson plan or in any of the included activities, the teacher can record different kind of observations: picture, video, document, snipped code, positive comment, negative comment, idea or general comment. These observations can be collected at any time and they will be automatically synchronized with the web automatically when Internet is available.

\subsection{Offline mode and automatic synchronization.}

A main advantage that is provided by the Edu-AREA Android App is the offline mode. This means that independently of the availability of Internet connection, the teacher can read the information about the lesson plans and register observations. If Internet is not available this piece of information is stored locally and a red "!" symbol inside a red circle is included to signal that it has not been synchronized to the server. The application checks the connection to the server regularly. When the connection is reestablished the synchronization is produced automatically. 
CBIE-LACLO 2015

Anais dos Workshops do IV Congresso Brasileiro de Informática na Educação (CBIE 2015)

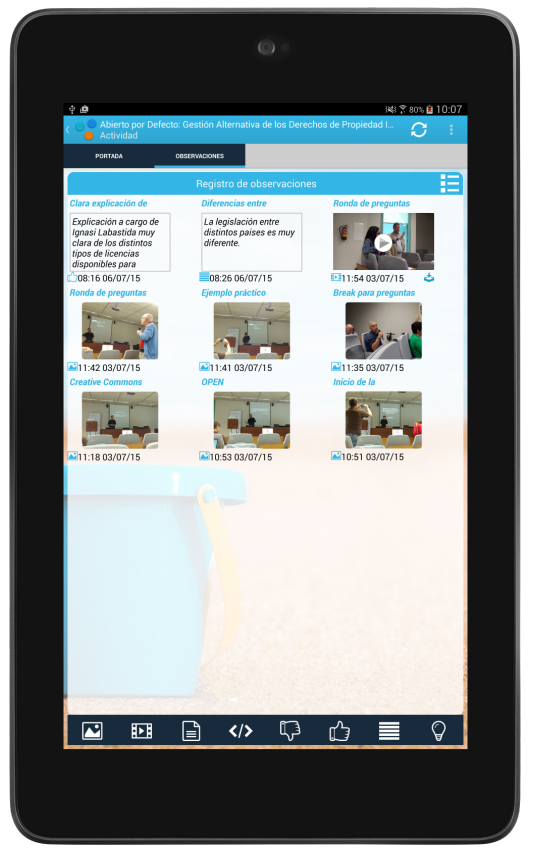

Figure 3. Edu-AREA App screen capture showing the observations

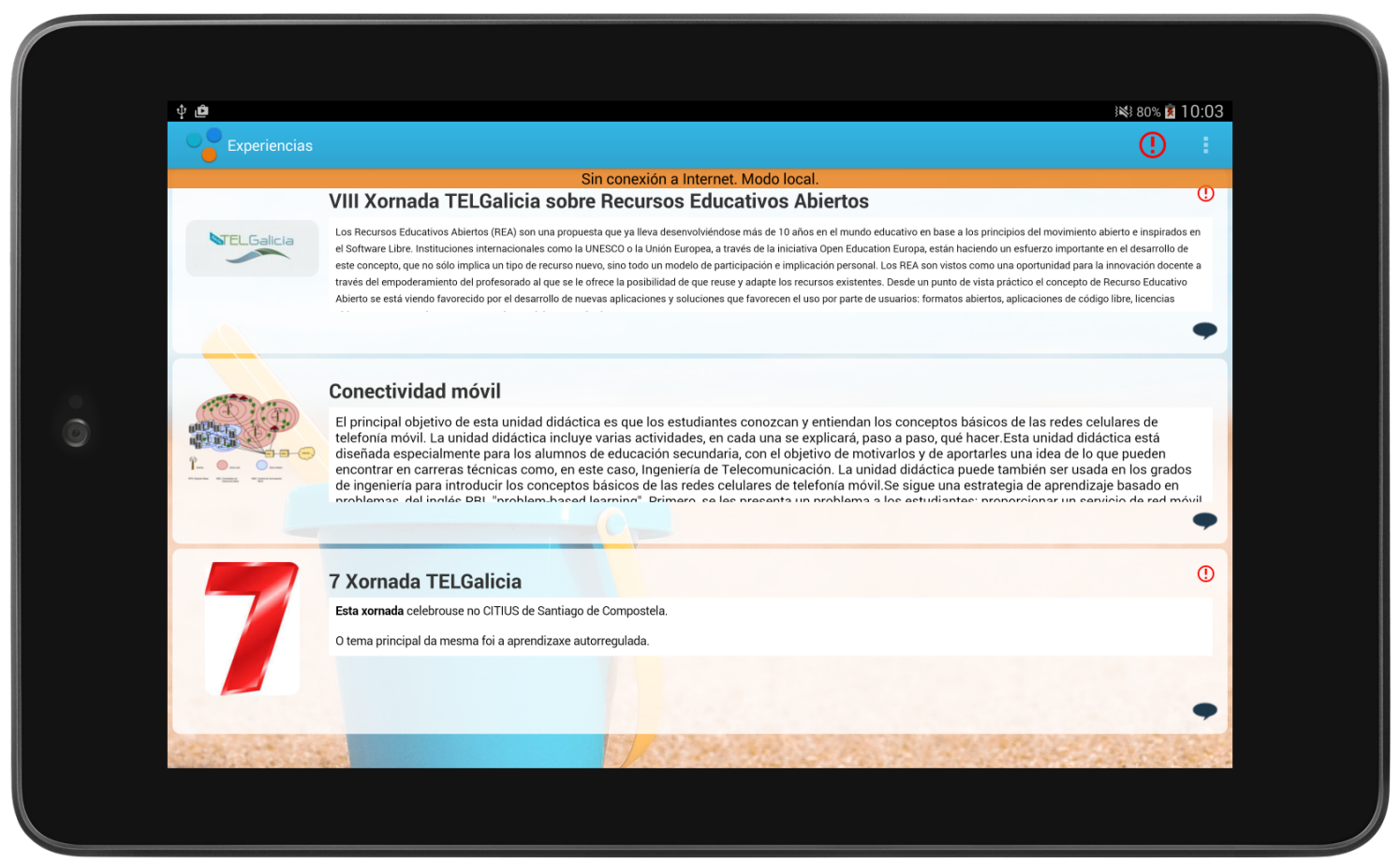

Figure 4. Edu-AREA App screen capture showing the signals related to the offline behavior and the synchronization status

\section{Conclusions and Future Work}

We want to support teachers on being more reflective and innovative professionals, to become responsible for their own teaching and not just reproducers of lesson plans designed elsewhere. We attempt to contribute to this innovation goal through the view of Open Lesson Plans. In this paper we introduce a definition of this concept and shown how it can be based on current teacher practices and technologies. The survey results 
shown in section 3 demonstrate that many teachers are usually involved in teaching planning, observation and reflection. The Android App shown in section 4 introduces some specific functionality. This functionality can be provided in a very easy way, without demanding extra effort for teachers and usable during class time (using a specific Android application). The goal is to increase the familiarity of teachers with evidence-based teaching and to facilitate the translation of research findings into teaching practices that enhance the quality of teaching delivered to learners (Laurillard, 2008).

\section{Acknowledgements}

This research has been co-funded by the Galician Regional Government under project R2014/029 "Research Networks: TELGalicia", the European Regional Development Fund (ERDF) and the Galician Regional Government under project GRC2013-006 (Consolidation of Research Units) and by the CYTED network 513RT0471, RIURE: Red Iberoamericana para la Usabilidad de Recursos Educativos (www.riure.net).

\section{References}

Caeiro-Rodríguez, M. (2014,). Opening Lesson Plans to Support Teaching Innovation and Open Educational Resources Adoption. In Proceedings of The International Symposium on Open Collaboration (p. 47). ACM.

Caeiro-Rodríguez, M., Pérez-Rodríguez, R., Garcia-Alonso, J., Manso-Vázquez, M., \& Llamas-Nistal, M. (2013). "AREA: A social curation platform for open educational resources and lesson plans". In Frontiers in Education Conference, 2013 IEEE (pp. 795-801). IEEE.

Camilleri, A. F., Ehlers, U. D. and Pawlowski, J. (2014). "State of the Art Review of Quality Issues related to Open Educational Resources (OER)". JRC Scientific and Policy Reports. doi:10.2791/80171

COM (2013). Communication from the Commission to the European Parliament, the Council, the European Economic and Social Committee and the Committee of the Regions. Opening up Education: Innovative Teaching and learning for all through new technologies and open educational resources. COM/2013/0654 final.

Laurillard, D. (2008). The teacher as action researcher : Using technology to capture pedagogic form 1. Studies in Higher Education, 33(2), 139-154.

O'reilly, T. (2007). What is Web 2.0: Design patterns and business models for the next generation of software. Communications \& Strategies, (65).

UNESCO. (2012). 2012 Paris OER Declaration. Paris. 